International Journal of Literature Studies (IJLS)

ISSN: $2754-2610$

DOI: $10.32996 /$ ijts

Journal Homepage: www.al-kindipublisher.com/index.php/ijlss

\title{
The Mythology of Defeat: The Yom Kippur War of October (1973) in Ada Aharoni's Toward a Horizon of Peace, New Historicist Reading
}

\author{
Dr. Mohammed Saleh Abdullah Hammad \\ Department of English Language, Faculty of Languages and Translation, October 6 University, Egypt \\ $\square$ Corresponding Author: Dr. Mohammed Saleh Abdullah Hammad, E-mail: mohammedsaleh.lang@o6u.edu.eg
}

\begin{abstract}
ARTICLE INFORMATION ABSTRACT
Received: 11 September 2021

Accepted: 01 October 2021

Published: 28 October 2021

DOI: $10.32996 /$ ijts.2021.1.1.7

\section{KEYWORDS}

Ideology, new historicism, power,

Using a New Historicist methodology, this paper explores the ideology in selected poems by Ada Aharoni. The paper begins by investigating the three major paradigms used by Israeli society to mythologize the Yom Kippur War. After that, an overview of the new historicism theory is presented, with a focus on the concepts of power and ideology. This helps to develop the argument of the paper into illustrating the connection between Aharoni and new historicism by discussing how she achieves her ideology in her poetry. Finally, the paper presents an analysis of selected poems from a new historicist perspective.
\end{abstract} war, Yom Kippur War

\section{Introduction}

\subsection{Mythologizing the Yom Kippur War (1973)}

The Yom Kippur (1973) is also known in history as the Ramadan War, the October War, the 1973 Arab-Israeli War. It is an armed war between Israel and an Arab coalition that includes Egypt and Syria. The War started when the Arab coalition attacked Israel on the Jewish holy day Yom Kippur, which had come that year in the same holy month of Ramadan. The fighting began with a successful massive attack by the Egyptian armed forces crossing the Suez Canal when they crossed the ceasefire lines with Israel and advanced constant and virtually into the Sinai territory. Israel, on its side, mobilized most of its forces three days later to halt the Egyptian army. At the same time, the Syrian army began their attack on the Golan Heights to coincide with the Egyptian attacks and they also advanced successfully into the Israeli-held territory.

The Yom Kippur War evokes a sense of bitterness among Israeli Jews. Many in Israel think of it as a disaster in the history of the nation and this is evident in referring to Israeli literature or in the way the War is recalled in the media every time on the anniversary of its outbreak. The Yom Kippur War can be described as a failure of the myth of the superiority of the Israeli army in the region. Consulting the Israeli press, popular books, and articles that tackled the War indicates the news of the great number of victims and casualties and the loss of territory which followed the conclusion of the war. There are also talks about the surprising nature of the attacks contrary to the speculations of the Israeli military and political elite. On the other hand, it indicates a lot about the failure of the Israeli intelligence community. The confidence in the leadership and the sense of security had been terminated. The conclusion of the War minimized the image of the Israeli superpower in the middle east in a way that jeopardizes the controlling ideology in the region. Consequently, the War magnified the inability of Israel to achieve a crushing military victory depending on the ideology that only Israel possesses the superpowers in the region. In addition, this shows Israel's impotence, and the nation will always be subject to security threats. This explains the Israeli desire to possess the state-of-the-art weapons and its conflicts and combats against Palestinian uprisals, Hezbollah south Lebanon, and its continuous intervention in neighbor and non-neighbor countries in the region.

Defining the relationship between war and myth from a political perspective is essential at this point. Henry Tudor in his book Political Myth (1972) defines the myth as "a story... a narrative of events in dramatic form... all events that actually took place; has

Auhtor's ORCID: https://orcid.org/0000-0001-9090-1897

Copyright: (c) 2021 the Author(s). This article is an open access article distributed under the terms and conditions of the Creative Commons Attribution (CC-BY) 4.0 license (https://creativecommons.org/licenses/by/4.0/). Published by Al-Kindi Centre for Research and Development, London, United Kingdom. 
not prevented them [myth-makers] from being made the subjects of political myth... what makes a myth as being political is its subject matter" (p.16-17). He also perceives that if a political narrative may be reacted as a myth, the narrative must possess a dramatic form and must serve a practical argument (p.16). Furthermore, he defines the "dramatic form", "there is indeed a critical event by reference to which men can order their present experience but the events in question are thought of as taken place in the past" (p.16). Regarding the objectives of the political myth, Tudor advocates that a good understanding of political myth needs the reader to recognize two main components. Firstly, the myth is that which provides the theoretical argument, which is incorporated into an ideology that supports the myth by providing a practical argument as the second component (p.127). This agrees with what Christopher G. Flood refers to in his book Political Myth (2002) when he defines the political myth by "an ideologically marked narrative which purports to give a true account of a set of past, present, or predicted political events and which is accepted as valid in its essentials by a social group" (p.44). Notwithstanding, Flood sees that both myth and ideology carry certain values and beliefs. He urges that ideology is a "set of myths" (p.107). On the other hand, an ideology consists of interrelated images and ideas that provide people with an understanding of a mythic map of their political world, shaping their political images and responses to their past, present, and future political community (p.107).

For instance, the Holocaust, according to the Israeli version, is depicted between the members of the Israeli society in a variety of forms that attained the meaning of the myth through the images of terminating more than six million Jews while the world did nothing to save them. From the Israeli perspective, this made them believe that their only salvation is to possess sovereignty in their so-called homeland. Employing myth has very significant importance in cases of defeat or any other nation's catastrophes. On the other hand, achieving victory or success must need an explanation of reasons, but it enhances nations' belief in its constants and establishes self-confidence, confidence in nations' political elite. People who have might sacrifice and suffer in achieving victory. Now they are comfortable with their contribution. But, in case of defeat, the tragedy and catastrophe challenge all with the loss of ultimate meaning. So, no surprise when one finds that the most important myths in history are built on stories and events that are regarded as a defeat but represented through the using of myth as a victory somehow. Martin S. Jaffee in his article "The Victim-Community in Myth and History: Holocaust Ritual, the Question of Palestine, and the Rhetoric of Christian Witness" (1991) refers to the process of mythologizing the Holocaust when he discusses the interrelationship between defeat, victimization, and myth. Jaffee perceives that victimization is deeply rooted in the memory of a nation as a moment of victory. This could be achieved through the religious imagination of myth. In this case, Jaffee believes, victimization can carry a kind of holiness and power upon the victim himself (p.236). Every time the stories of murdering the innocents are retold, the original moments of the victim's destruction are reconstructed. In this sense, the victim has always portrayed a victim and a victor at the same time and always terminated, but always reborn in a way that overcomes the victimizer (p.236). Jaffee believes that through the process of keeping retelling the stories of the victim:

The community of victimization not only memorizes the victim and stands in solidarity with the victim's fate; it also shares the victim's triumph and transformation, bringing in its history the power of its myth and mapping onto its own political and social reality the mythic plot through which comes to self-understanding as a community of suffering. (p.236)

In terms of mythologization when a series of events are recalled in the form of disaster, the researcher finds that the Yom Kippur War seems to have the same case and it could be approached through three different paradigms to be defined as a myth in Israeli society. Firstly, Robert Wistrich and David Ohana approached the War in their book The Shaping of Israeli Identity (1995), through a paradigm named after the holy day of Purim that Persian Israelis celebrate their salvation. Briefly, it's a story of overcoming an impending threat to Jewish life. In this story, the victory looks natural, but people believe it's miraculous. According to the story, this victory is a sign of Jewish power and what they perceive as the support of God who is the source of their power. This was also accompanied sometimes by the indignity of the Jew's enemies (p.163). Israeli society perceives that Yom Kippur War has all the elements of the Purim paradigm. The researcher finds that this paradigm becomes invalid because the religious public failed to mythologize the War in terms of the elements of the Purim paradigm. They acknowledge that the miracles had taken place in the Yom Kippur War, but they refused to portray the War in terms of the Purim paradigm. (p.169)

Secondly, In The Yom Kippur War: The Epic Encounter That Transformed the Middle East (2004) Abraham Rabinovich attempts the Bravery paradigm, that spotlights the loss of human life, young people in particular, and this is supposed to be unnatural and must be subjected to investigation. According to the Bravery paradigm, the focus on the implications of the loss of lives especially in times of wars is the essential purpose of every society's leaders as well as the intellectuals (p.118). If the loss of lives becomes meaningless, the victims and the grieving families remain without solace and all members of the society are under the threat of chaos. This agrees with what George L. Mosse mentions in his book Fallen Soldiers: Reshaping the Memory of the World Wars (1991) when he refers to the wars of the French Revolution (1792-1799) and the German Wars of Liberation against Napoleon (18131814) "saw the origins of the Myth of the War Experience, which fulfill a need that had not existed in previous wars... had been fought by mercenary armies with little stake in the cause for which they fought" (p.9). Furthermore, Mosse elaborates that "Myth if the War Experience means understanding the role of volunteers who so largely produced it... War was made sacred, an expression 
of the general will of the people" (p.32-33). According to Mosse, although the death and loss of lives of the fallen soldiers lead to nothing has been achieved, people of the bereaved society console themselves about the death of soldiers by retelling the stories and events of their death as stories of heroism and bravery. This paradigm also becomes invalid, because the brave soldiers on the battlefield of the War were already celebrated and Israeli history and culture keep remembering stories of those soldiers with great courage, but when it comes to the War as a whole it has not remembered in that light and this goes unlike other examples like the War of Independence, The Arab-Israeli War of 1948, that broke out when five Arab countries attacked occupied territories in Palestine and immediately followed by the announcement of the independence of the state of Israel on May 14, 1948.

The year 1979 witnessed the signing of the peace treaty, Camp David, between Israel and Egypt after the visit of the Egyptian president Anwar Sadat. Israeli people welcomed the peace treaty as if it was a beginning of a new era in the history of relationships between Israel and Arab neighbor countries. In this course, the third paradigm occurs, the Consequences Paradigm, in which Israeli society believes in the mythologization of the Yom Kippur War because it's understood that by the peace treaty with Egypt, the most imminent threat to Israeli society is eliminated and Yom Kippur War becomes a fundamental element that led to the Camp David peace treaty. Consequently, whatever cost Israel and might have paid in soldiers' lives, it becomes worthwhile. Yossi Katz in his book The Tombstone in Israel's Military Cemetery since 1948 (2014) advocates this concept when he says, "In the wake of the Yom Kippur War the phenomenon of embellishment on the tombstones of those who fell in the war again became widespread" (p.366). Although all these attempts of defining the Yom Kippur War as a myth, Israeli society failed to remember the war as a case of miraculous salvation. The question is why poets like Ada Aharoni, after more than 40 years after the end of the war, went back again and remember Yom Kippur in her volume of poetry Toward a Horizon of Peace (2018)?

\section{New historicism: beginning}

One branch of historiography is historicism. In Raman Selden, Peter Widdowson, and Peter Brooker's A Reader's Guide to Contemporary Literary Theory (2017), there are two contradictory approaches to literary history throughout the 19th century. One presents history as "a series of isolated monuments and achievements of individual genius" while the second is historicist who saw literary history as part of a large cultural history" (p.166). some historicists, who are influenced by Hegelian idealism and Herbert Spencer's evolutionary naturalism, study literature in the context of social, political, and cultural history, in a way that places history as the background of the literary texts. However, in A Glossary of Literary Terms (2015), M.H. Abrams, and Geoffrey Harpham urge that "the literary text is situated within the institutions, social practices and discourses that constitute the overall culture of a particular time and space, and that the literary text interacts as both a product and a producer of cultural energies and codes" (p.183). It does not approach a text in isolation from its historical context. New historicists focus on the historical and cultural context of the literary text. It's not a simple return to the old historical approach, because the former scholars had taken the social and intellectual history as the background of the literary works, and they had worked hard to divide history into different periods and layers. On the other hand, the new historicism views literature as the reflection of the worldview of a period. According to new historicists, history is not merely the background of literature anymore. Literary texts not only represent the conclusion of a cultural conversation in one historical period but also participate in that relationship. Literary texts are vehicles as well as consequences of cultural change and become parts of the documents that compose and make history.

Stephen Jay Greenblatt is the first who coined the term "new historicism" in his introduction to a special issue of Genre, Vol 15 (1982). Just as every literary criticism that takes in the elites of the previous criticism, new historicism is mainly the outcome of concepts and perspectives of literary analysis and interpretation that have been comparable to different post-structural theorists, particularly Louis Althusser's Marxist ideology, Michel Foucault's discourse and concept of power, the central concept in deconstructive criticism. The outstanding Marxist, Louis Althusser, creates the illustrative reading method which has an influence on Stephen Jay Greenblatt a lot. The term "symptom" is originally a medical term and Sigmund Freud uses it to describe the inconscient psychological forces in psychological analysis. Usually, these psychological forces are depressed, and they can only go into the consciousness when the depression becomes flexible or disappear at random. Thus, Louis Althusser develops it into the symptomatic reading method. Readers should understand that the multiple conflicts of the texts and the ideology which originates from politics, economics, religion, and other fields must be taken into consideration. Althusser believes that his symptomatic reading motivates the new historicists to dig deep into meaning from different prospects and it supplies the method to explain the texts for new historicism.

The French philosopher, Michel Foucault's discourse and his power theory have a deep influence on new historicism which takes history as discontinuous and narrative. Foucault perceives that history is in discontinuity and his discourse theory is used to support his ideas. In social practice, discourse is a language that refers to the statement and representation of the social and cultural elements. Foucault's discourse refers to realize which is a single set of structured statements, and the discourse concept is continuous and diverse. Discourse is the application of language in social and cultural practice, and it is a system of verbal language and written and unwritten text symbols. The discourse which is related to power could be negative and repressive. According to Foucault, power does not only produce things but also induces pleasure and forms of knowledge. According to new historicism, the concepts, ideas, and structures of agencies can be traits to the circulation and exercise of power. The power is not monolithic, 
and the power relations always imply multiple sites not only of power but also of resistance. Foucault's concept of power relations may adapt local instances of a subversion that is created for the purpose of containment. Subversion and containment are significant concepts in new historicism, and relevant to the topic of this paper as well. Clifford Geertz's symbolic anthropology influenced the new historicists of the 1970s and 1980s. The typical literary comments of new historicists make use of the Geertzian model of thick description in the initial deployment of an exemplary anecdote as a strategy of cultural and historical estrangement. Geertz perceives that culture is the vehicle of semiosis, a set of control mechanisms, such as plans, recipes, rules, and instructions, for the governing of behavior and a system of social life by controlling the making of those conventions, practices, and artifacts to which the word culture is often loosely applied. Geertz explains culture as a model and remarkable literary approach for a culture of individual and collective human beings that could be in action and culture lived in the performances and narratives. This type of rhetorically self-conscious ethnographic practice is the thick description. This thick description can also be explained as the hermeneutical narration and it captures events, performance, and other practices.

The poststructuralist intellectual revolution, in the 1960s and 1970s, challenges the old historicism on several levels and establishes a new set of assumptions: Firstly, history is always narrated, and the past is always in the form of representations, so the first sense is not accepted. Secondly, there is no single absolute history, only discontinuous and contradictory versions of histories. Thirdly, the past is not something that opposes us as if it is a physical object but is something we build from already written texts of all kinds of which we interpret in accordance with our particular historical concerns. Fourthly, history is always a matter of retelling stories about past events, using other texts as our intertexts and literary works should be regarded as texts among other texts. In Andrew Bennett and Nicholas Royle's book An Introduction to Literature, Criticism, and Theory (2016), these academic ideas are very different from the old historicists who hold the views that history is not so much textual as more simply "a series of empirically verifiable events" (p140). The new historicists argue that any knowledge of the past is necessarily mediated by the current authorities and history is textual in many respects. New historicists pay more attention to the conflict and contradiction in suspense, and they take the marginal events and figures the same way with the mainstream. Instead of praising the existent aesthetics, new historicists focus more on exploring the formation process of the ideology and the material basis. In The New Historicism (1989), Harold Veeser perceives that the new historicism is not a single methodology but a kind of literary criticism practice (p.xi). Vesser says "New Historicists combat empty formalism by pulling historical considerations to the center stage of literary analysis" (p.xi).

Greenblatt's subversion and containment mode have been accepted commonly in the field of Shakespeare and Renaissance and his anecdotes which analyze. the texts from both literature and non-literary material, from the mainstream and the marginal, are widely adopted by the new historicists and are used by the new historicism as thick descriptions. Greenblatt also borrows the terms social energy, circulation, exchange, and negotiation from economics and makes use of them to analyze the literary works of the Renaissance. This means Greenblatt perceives that the process of reading a literary text considering new historicist theories entails reading both literary and non-literary texts as constituents of historical discourses that are inside and outside the text. Practitioners and critics of new historicism work become the exploring the connections between texts, history, culture, and the author's biography. Greenblatt's perspective meets what Vesser presents when he thinks that new historicism has given scholars new opportunities to span the borders of separating history, anthropology, art, politics, literature, and economics.

In short, new historicism pays more attention to literary practice than theoretical construction, and different representatives have different proposals. Jerome J. McGann in his book Historical Studies and Literary Criticism (1985) says, "the core of new historicism centrally concerns with the relationship between history and text, the commonality between historical and literary texts" (p.18). Vesser in his The New Historicism (2016) summarizes new historicists' theoretical assumptions in every expressive act, including literature, is embedded in a network of material practices (p.16). Every act of unveiling, critique and opposition uses the tools it denounces and risks falling prey to the practice it exposes (p.16). Literary and non-literary "texts" circulate inseparably; no discourse, imaginative or archival, gives access to unchanging truths nor expresses inalterable human nature (p.119). A critical method and language adequate to describe culture under capitalism participate in the economy they describe (p.158). The previous discussion of New Historicism shows that there is no unified and continuous "History" but only the discontinuous and contradictory "histories". Since history is full of textuality, the past can never be viewed in authentic and pure form.

\subsection{New historicism: ideology and power}

New historicism attempts to rehistorize all texts, literary and non-literary, and gives due weight to the cultural context in which they were created, meaning, impact, interpretation, and evaluation, i.e., literary texts are created and actualized in cultural contexts, not in a vacuum. According to Chris Murray's Encyclopedia of Literary Critics and Criticism (1999), new historicism is unlike the old school. It "operates by fusing 'linguistic turn' of post-structuralism and deconstruction and a return to historical readings" (p.806). New historicism provides a comprehensive methodology for studying literature as a text and it assimilates the linguistic turn of poststructuralism and the ambiguous nature of literary text propounded by deconstructionists, which is always under erasure (p.806). These methods tend to focus on a work's textual analysis, yet the connection between new historicism and these linguistic methods cannot be overlooked because literature has its own historicity. This means that history can only be accessed in textual form, and this canon of textuality in history and historicity intext blurs the border between literary and non-literary texts. In 
"Approaching New Historicism" (2004), Renu Paul Ukkan advocates that "New Historicism involves a parallel reading or juxtaposition of the literary and the non-literary text of the same historical period. Both are given equal importance and allowed to work as sources of information and interrogation with each other" (p.22-33). This concept of textual historicity and textuality of history opens a unique way of textual analysis known as intertextuality, and it indicates that a literary piece is comparable to other texts from other areas of knowledge in that sociocultural context. For new historicists, the term 'intertextual' draws emphasis to the concept of 'con-text,' meaning that there is no distinction between literary and historical text, Cuddon explains "[this] way, the non-literary text becomes not a con-text but a co-text, along with literary work. The literary text is placed with the framework of non-literary text which is closely read" (Cuddon,2014, p424).

New Historicists' critical strategy is noteworthy since they value both text and embedded historicity equally. New Historicists, influenced by Michel Foucault's concept of discursive analysis of power relations, have developed a new political reading technique for texts. Power relations are represented in discourses that are not overtly expressed but are implicitly expressed in the text. Murray agrees with this perspective when he finds that, new historicism is "aspired to a politics of culture" (p.806) which is covertly manifested in a text because power structure is administered by the state. He continues "The state's control of its citizenry was internal rather than external (p.808). The state subjected its people by creating them as subjects, devising fixed categories under which people could be described and thus controlled. This was the conjunction Foucault evoked as Power Knowledge" (p.809). Literature influences and is influenced by these micro-forces operating in parallel in the society of which it is a product, and so controls and is controlled by them as a power operator and operator. Michel Rayn believes in the influence of Foucauldian power politics on textual historicity of new historicists: "The new historicists were primarily influenced by the analysis of power and the historical studies of Michel Foucault, whose work shifted critical interest from the macro-narratives of politics and economics ... toward the micro-logical discursive practices" (Rayn,2017, p.29).

Apart from the effect of Foucault on the new historical-critical canon, Greetz's perspectives regarding power and ideology in new historicism are significant, because new historicists begin to read texts as dense [thick] cultural descriptions and this agrees with what Ukkan remarks in his article:

This sort of analysis makes New Historicism establish Clifford Geertz's use of the term 'thick descriptions'. Colebrook explains that Geertz employs the term in the New Historicist way of analyzing a particular social event which as meaning for people involved and discovering the patterns of conventions, codes, and modes of thinking that attribute those meanings to a cultural event. (Ukkan,2004, p.23)

Murry believes that what Geertz means by "thick description" is that "thickly describes unearths the underlying meaningful structures of local events and local interactions and from those interactions generalizes whole societies" (Geertz,1999, p.807). An anthropologist, according to Geertz, conducts a rigorous and systematic study of a specific culture and human race to determine how power structures operate and exert their influence on human beings. He works on a little event or incident, attempting to convey the spirit of culture through the dense description. As a result, new historicists should try to evaluate a single event, scene, or extract in any book that gives rise to fragmented voices and designates events, considering the detailed description shown implicitly in the text at hand. This is the main reason beyond that the "Cultural Poetics" is influenced largely by Greenblatt and "thick description" can be taken as another name for Cultural Poetics.

This connection between present and past in analyzing a literary text is very significant in shaping the ideology of the text. New historicists emphasize the need for the critic's awareness while studying a text because the critic is from the present yet must read a text published in the past and reconstruct the past with two types of historicity at work. D.G Myres remarks:

The historian/critic is trapped in his own 'historicity'. No one can rise above his own social formations, his own ideological upbringing ... A modern reader can never experience a text as its contemporaries experienced it. Given this fact, the best modern approach to literature can hope to accomplish ... to use the text as a basis for the reconstruction of an ideology. (Myres,2006, p.27)

As a result, the new historicists' approach to studying literary texts is to treat the text as the primary source on which the reader's current circumstances and reconstructive faculty operate, imposing meaning on it. This comes in accordance with what Abrams refers to when he says:

New historicists acknowledge that they themselves, like all authors, are

'subjectivities' ... The textual meanings they describe and the literary and cultural histories they narrate... They stress that the course of history between the past and present is not coherent, but exhibits discontinuities, breaks, and ruptures; by doing so, they hope to 'distance' and 'estrange' an earlier text and so sharpen their ability to detect its differences from their present ideological assumptions. Some 
historicists present their readings of text written in the past as 'negotiation' between past and present. (Abrams,2015, p.186)

According to new historicists, the political interpretation of a text is important since any document, whether literary or non-literary, is a cultural construct that shows the political, social, religious, and economic circumstances and ideologies of the time. Abrams continues:

Political readings of a literary text ... which they [New

Historicists] stress quasi-Freudian mechanisms such as 'suppression'

'displacement,' and 'substitution' by which, they assert, a writer's political ideology inevitably disguises, or entirely elides into silence and 'absence,' the circumstances and contradiction of contemporary history. The primary aim of the political reader is to undo these ideological disguises and suppression in order to uncover the historical and political conflicts and oppressions that are the text's true, although covert or unmentioned, subject matter. (Abrams,2015, p.187)

Immediately this must remind one of what Althusser advocates "literature is one of the institutions which participate in making state power and ideology familiar and acceptable to the state's subjects" (Althusser, 1971, p.12). According to Althusser's theory, literature reflects the values, customs, and conventions of the society's dominant interests, and is thus mobilized by the state as an ideological weapon, an army of metaphors that seeks to convince and manipulate rather than coerce, mostly unintentionally (Althusser, 1971, p.12). Abram's statement shows that new historicists are influenced by theorists such as Ronald Barthes and Michel Foucault, who attribute value to discursive texts and deny the presence of the author's "empirical self," but cannot dismiss the author's "implied self". This agrees with what Bijay Kumar Das quotes from Barthes when he says, "the author cannot come back into text. . . he can only do so as a guest" (Das, 2000, p.107). It suffices to say that a writer appears in his work as a mask for his ideals and ideology, which are unwittingly represented in the text (Das,2000, p.107). The writer appears to be consciously unconscious to hide his identity behind his ideologies, and the presence of certain ideologies reveals that the author is influenced by his own cultural conditions and that he is aware that the role he plays is not that of a social reformer, but rather to give the readers a hint.

In new historicism, power is possibly the most elusive phrase. It's more commonly used by new historicists, who prefer to utilize Marxist terminologies like ideology and hegemony. Power, according to Foucault's History of Sexuality (1981), refers to the relations of dominance and resistance that pervade our social, political, and cultural interactions, but it may also relate to the ways in which power is a productive, even enjoyable, aspect of our lives (p.96). In new historicist analysis, power oscillates between repressive and creative, and one of the most enigmatic characteristics of the phrase is that it appears to emerge from and be applied to us. This investigation was carried out by Althusser in Lenin and Philosophy(2001), specifically in the essay "Ideology and the Ideological State Apparatus" (p.96) where he divides the state's functions into the Repressive State Apparatus (RSA) and the Ideological State Apparatus (ISA) in this essay (ISA) (p.98). The former, through the police and army, relies on the threat or use of violence to preserve order. The latter is based on the material institutions of education, religion, politics, and so on, which help to build social norms and parameters. According to Althusser, a society's behaviors and ideas are determined by its ISAs. Althusser asserts:

Ideas have disappeared as such (insofar as they are endowed with an ideal or spiritual existence), to the precise extent that it has emerged that their existence is inscribed in the actions of practices governed by rituals defined in the last instance by an ideological apparatus. It, therefore, appears that the subject acts insofar as he is acted by the following system (set out in the order of its real determination): ideology existing in a material ideological apparatus, prescribing material practices governed by a material ritual, which practices exist in the material actions of a subject acting in all consciousness according to his belief. (p.43-44)

By highlighting the tension and contradiction at the heart of "history" and "representation", Marxism paved the ground for a fullscale analysis and challenge of the processes and forces of ideology or power, which is what new historicism aims to do.

\subsection{Ada Aharoni: shaping ideology of the poet}

Significantly, Ada Aharoni is an Israeli poet who was born in Egypt. One of the main themes in many of her works is the uprooting of Jews from Egypt, including herself, during the founding of Israel in 1948. Her career has revolved around her studies into the "Second Exodus." Aharoni used the phrase "Second Exodus" to describe the forced departure of Jews from Arab countries after the State of Israel was established in 1948. In a joint article titled "Possibilities of Israeli-Palestinian Conflict Resolution Based on 
Mutual Recognition of National Aspirations", Aharoni and her husband, Haim Aharoni, argue that Palestinian refugee settlement in Israel should be limited and that if refugees were "returned" to the area that has become part of Israel, they would be in a foreign land:

Processes that take place in a society are rarely reversible processes, repair of wrongs and compensation on suffering cannot usually be accomplished by a return to the previous situation but by the creation of a new situation that is beneficial while appropriate to the new conditions.

https://web.archive.org/web/20131012045845/http://iflac.com/ada/docs/Haim\%20Article.ht

ml

Wilfred Owen, a British peace poet, became an inspiration for her own works. Many consider Owen to be the best poet of the First World War, with verses depicting the horrors of trench and gas warfare. He has a significant influence on shaping Aharoni's ideology about war. Joel Beinin in his book The Dispersion of Egyptian Jewry (2005) advocates that "In most of Aharoni's first published poems on the theme of war and peace, her Egyptian origins linger discreetly in the background" (221). He examines the diversity of Egyptian Jewish identities in Egypt and in the diaspora:

In most of Aharoni's ... poems on the theme of war and peace ... The Egyptian-Israeli Selected novels and Poetry Books Poetry Peace poetry negotiations and interim Sinai disengagement agreements following the 1973 war apparently encouraged her to advance beyond general calls for peace to articulate more specifically what peace meant to Aharoni through recollections of her previous life in Egypt. (p.221)

Some of her poems about war deal with Israel's struggle for survival, such as "To an Egyptian Soldier", which is written during the Yom Kippur War, in which Aharoni tells him, "You will always have your Nile/ but if we lose, there's only the sea" (p.69). Her recollection of being an outsider, unwelcomed, and not belonging in Egypt is the root of her deep commitment to her new homeland. In this course, in the Preface to Aharoni's Poems from Israel (1992), Len Goldzweig, a lecturer in the Department of English at Haifa University, writes:

She recalls this sense of alienation in Arab Israeli Student on T.V., where the student ponders on where he belongs: Do I feel like an Israeli Arab? Or like an Arab Israeli? "I remember my own rootless wound in Egypt land, and I hurt your dangling hurt, my Semitic cousin in pain." (p.7)

Aharoni is conscious of the significant role poetry can perform. Poems, she feels, are effective vehicles for establishing trust and respect and delivering messages and ideologies. Among the examples that demonstrate this concept of delivering or shaping an ideology in this paper are two poems by Aharoni; "This Cursed War" and "Remember Me Every Time the Moon Rises Over the Sphinx" in which the poet claims that she was inspired by Israeli and Egyptian soldiers during the Yom Kippur War. She alleges that she writes from the point of view of the two conflicting sides. "Knowledge of each other is the only way to overcome cultural divides amongst human beings," Aharoni told Birute Regine in an interview for Regine's book Iron Butterflies: Women Transforming Themselves and the World.

\section{Yom Kippur War in Ada Aharoni's Toward a Horizon of Peace: new historicist reading}

New Historicism attempts to rehistorize all texts, literary and non-literary, and gives due weight to the cultural context in which they were created, meaning, impact, interpretation, and evaluation, i.e., literary texts are created and actualized in cultural contexts, not in a vacuum. US President Donald Trump ran for the presidency as a disrupter. When it comes to his managing of the US-Israel relationship, he has been precisely that. Throughout 2018, Trump took several decisions that will have far-reaching consequences for Israel's future, its conflict with the Palestinians, and its efforts to impede Iran's ambition for a nuclear weapon and regional dominance. Throughout it all, he has kept Israel in the spotlight and made it a priority for his administration. In typical Trumpian fashion, the president made the year 2018 one of upheaval and controversy. Here are the five ways that he upended US-Israel relations in 2018. Firstly, Trump made good on his promise to move the US embassy from Tel Aviv to Jerusalem in May. The move was warmly praised by Israel, but it caused overwhelming anger in the Arab world against US and Israel. Secondly, Trump withdraws from the nuclear deal with Iran. Thirdly, Trump cuts vast sums of US aid to Palestinian organizations and UN groups that support Palestinians. Fourthly, Trump gives his orders to pull all US troops from Syria. Fifthly, the US president announces his peace plan which remains a question mark, with the potential to one day reshape both the US-Israel relationship and the broader Middle East.

For Israel, the year 2018 could be regarded as a golden year that comes after various incidents of relapse and failure during the 2000s. For example, in May 2000, Israel loses a lot in its conflict with Hezbollah in Lebanon and withdrew from southern Lebanon. January 2001 witnessed the failure of last-ditch efforts at restarting Israeli-Palestinian talks in Taba, Egypt, and attempts to stop 
Palestinian protests failed. In the year 2002, Israel suffered from a lot of suicidal bombings. In the same year, Israel began to build a barrier in and around West Bank, but in July 2004, the International Court of Justice issues an advisory opinion that the West Bank barrier is illegal, and this was also classified as a failure before the world. In May 2010, Nine Turkish pro-Palestinian activists were killed in clashes during Israeli boarding of ships attempting to break the blockade of Gaza. Relations with Turkey approach breaking point. Israel apologizes for its deaths in 2013. July 2014, in response to armed group attacks in Gaza, Israel launches an air-land military campaign to destroy missile launchers and tunnels. In August, the fighting comes to an uneasy close with an Egyptian-brokered ceasefire. In December 2016, Israel suspends working ties with 12 countries that voted for a Security Council resolution condemning settlement building, after the US for the first time abstained from the vote rather than using its veto.

Toward a Horizon of Peace published, May 15, 2018, one day after moving the US embassy from Tel Aviv to Jerusalem announcing that Jerusalem is the capital of Israel arouses questions about the significance of this book particularly the time of publication in connection with the overwhelming anger in the Arab world against Trump decision. The Washington Post (2017) anticipates the consequences of this decision in 2017 by reviewing the expected reaction of some leaders from Arab and Islamic countries. The US newspaper quotes the Saudi Press Agency in Riyadh, King Salman bin Abdul Aziz cautioned Trump that "that such a dangerous step of relocation or recognition of Al-Quds as the capital of Israel would constitute a flagrant provocation of Muslims, all over the world". the Turkish President Recep Tayyip Erdogan declares that US recognition of Jerusalem is a "red line for Muslims, possibly forcing Turkey to cut diplomatic ties with Israel". Through her volume of poetry, Ada Aharoni carries the Arab-Israeli conflict and the Israeli ideology towards the Arab world to a literary dimension.

Aharoni is aware of the importance of the Yom Kippur War (1973) for the Arab world and Egypt in particular. The 1973 War is iconic in which Egypt and Syria had perfect conditions to accomplish their operational goals. They took advantage of strategic surprise, overwhelming numerical superiority, a simultaneous two-front assault. The Arab-Israeli War of 1973 demonstrated that military victory is not exclusively dependent on numbers or equipment. What matters most is the capacity to respond to the circumstances and perform effective combined weapons integration, as well as officers' initiative, doctrine, training quality, and equipment familiarity. This dispute is a good example of what might happen when a defender uses the "modern system" to defend against attackers who did not. If one reads the history of this region carefully, one understands the meaning of placing the Yom Kippur War (1973) versus moving the U.S. Embassy from Tel Aviv to Jerusalem in 2018. Israel visualizes the moving of the US embassy as a victory over its enemies. These two moments of triumph are present to Aharoni's mind while she was writing Toward a Horizon of Peace (2018), which after more than 40 years tackles Israeli defeat in 1973. Reading this book unveils the ideology that the poet tries to establish in the minds of readers especially when the poet comes to talk about the Yom Kippur War claiming that she is inspired once by an Israeli soldier's diary and then in a different poem she is inspired by Egyptian soldier's diary.

In Aharoni's poem "This Cursed War", she advocates that at the beginning of the poem that she is inspired by an Israeli soldier's Yom Kippur War Diary which is found in the Golan, October 1973. Immediately this identifies that the poet writes from the Israeli point of view.

The night creeps long, funeral throng

Memories rush and flood blood.

Fresh list of dead thumps red.

Every name pins mind with whizzing missiles,

Cursed, cursed war! (Aharoni,2018, p.53)

The first stanza states immediately the atmosphere and circumstances the Israeli soldiers were living in at the war of 1973. It is rich with dictions and symbols of death everywhere and in every line when the poet says: "funeral, flood blood, dead thumps" (p.53). Then she concludes this stanza with how the Israeli feelings regarding this war that they lost on the same day they are supposed to celebrate a holy day "Cursed, cursed war" (Aharoni,2018, p.53). The poet imagined herself as if she is the soldier and she tries to focus on portraying this picture of a soldier losing a war and who was left alone staring at the dead bodies of his friends: "I watch skeletons of tanks, crowned with names of friends, / Fresh bodies - old smell" (Aharoni, 2018, p.53). Then again, she concludes with the same tone "Cursed, cursed war" (Aharoni,2018, p.53). Then Aharoni registers the strength of the sudden attack of the Arab sides in "It doesn't look at all like wars in films this war, / Here we do not get a chance to shoot or wave a flag," (p.53). Aharoni here admits the failure of the ideology that was controlling the region before the war, because of the power and hegemony of the Israeli army. One can listen to a multilayer of voices in the poem. Sometimes, the reader feels and listens to the voice of the Israeli soldier, and sometimes the poet herself is the speaker of the poem. Then when Aharoni keeps repeating "Cursed, cursed war", it's normal that the war must be called so from the side of the one who loses the war.

God, let it stop, let it end, Let the nightmare end!

Cursing is the only shelter

I can creep into, as into a mother's womb, 
Not to crumble before thoughts in the dark.

Cursed are those who force me to be here

Cursed be this cursed, cursed war! (Aharoni,2018, p.54)

The last stanza concludes Aharoni's message about losing the war where she finds no escape from this catastrophe except creeping back into her mother's womb.

The poem "This Cursed War" should be taken into consideration along with her poem "Remember Me When the Sun Sets Over the Pyramids", that Aharoni claims that she is inspired by an Egyptian soldier's diary found in the Sinai after the Yom Kippur War (1973). Like the previous poem, Aharoni repeats here the same technique and ideology. She imagines herself in the place of a soldier fighting in the war, but this time it's an Egyptian soldier. The speaker of the poem here begins with writing a letter to his beloved "Leila":

Dear Leila, to you my love

I breathe my last letter.

I love you in all the ways love means,

Remember me every time the sun sets over the

Pyramids and the moon rises over the Sphinx (Aharoni,2018, p.70)

What is significant in this poem is that Aharoni tries to put both the Israeli and the Egyptian soldiers on the same level from the war. She wants the reader to understand and believes that both sides, Israeli and Egyptian, have the same perspective and impression from the war. Aharoni fails to achieve this, and her poem is unconvincing. "Remember Me When the Sun Sets Over the Pyramids" depends mainly on making an Egyptian soldier retell and memorize his memories with he beloves "Leila". Aharoni tries to insert the concept of hating and cursing the war in the minds of non-Israeli readers in general and the Egyptians in particular. She is aware of the difficulty of doing this and presenting the winning side of the war as the side that hates that war and curses it although this side won the war and successfully regained his occupied lands. Aharoni continues, "Of my enrolling at the cursed military college. / I loathe the hours a man goes through, waiting for death. / That we Egyptians, would never begin a war / But we have been ordered to cross the Suez Canal," (p.70). Aharoni fails to establish this ideology because this comes completely contrary to the public impressions about the war. Consulting some sources such as Al Ahram Newspaper, journalist Dina Ezzat in her article "Remembering the 1973 October War" (2018) conducts some interviews with the public especially the war 1973 generation. In one of these interviews with Medhat Mounir who witnessed the war, she quoted him "I was very young at the time, but I remember the day very well. I had been hearing news of possible hostilities with Israel from my parents and uncles. but then I got to learn first-hand what war was about" (Ezzat 2018). Mounir asserts that he still can remember the moments of victory of war 1973 "It was a moment of joy" (Ezzat 2018). Ezzat in another article "The 6th of October war: A tale of resilience and glory" (2020), she interviewed Khalil Al-Mahdi, who led military engineer in Battalion 603, where he retells his memories about controlling and getting hold of the Kabrit strongpoint. In this Al-Mahdi expresses the ideology of Egyptian soldiers during the war in 1973 which is opposed to the alleged ideology that Aharoni tries to present in her poem. Al-Mahdi says:

It was a tough war, and we were short on military equipment, but we never lost our morale or resolve, and we were willing to do whatever it took to keep in control of this strong point. We knew that our presence there was essential to curbing the counter-offensive of the Israelis or at least to limit it if it had to happen... There was little food and water, mostly taken from the strongpoint, and our military equipment was low. We were fully aware of the fact that at any minute things could take a disturbing turn. But somehow, we did have a strong faith that we could prevail. We just thought that there was some power that was there for us... we have believed in the chances of survival for wounded soldiers that we had put on floating pieces of wood and put in the canal, hoping that the current would take their bodies in the direction of Suez where they would receive treatment.

(Ezzat 8 October 2020 edition of Al-Ahram Weekly)

What Al-Mahdi says regarding their faith in their message in war is significant and opposed to that impression that is given by the Egyptian soldier in Aharoni's poem. Additionally, the soldier of the poem gives the sense of desperation and losing hope in life. But Al-Mahdi, as a real soldier, gives another sense that advocates the Egyptian soldier's ideology and strength hope in life when he says "we have believed in the chances of survival for wounded soldiers that we had put on floating pieces of wood and put in the canal, hoping that the current would take their bodies in the direction of Suez where they would receive treatment", this completely opposed to that image and ideology in Aharoni's poem.

What gives credibility to what AL Ahram Newspaper published is what William A. Rugh, deputy assistant director for Near East and North Africa of the United States Information Agency, in his article "Arab Media and Politics during the October War" (1975) 
presented when he examined newspapers published during the October War in several Arab countries. Rugh perceives that the Arab newspapers and media reporting during October 1973 was straightforward and reasonably free of deliberate bias. He finds that Arab media used the word "aggression" to refer to Israeli moves against the Arab countries and to reinforce Arab popular determination to fight Israel (Rugh,1975, p.311). Rugh advocates that there were signs during the 1973 war that some Arab media made a concerted effort to abide by factual reporting, for different reasons. First of all, it was easier to report the war accurately in 1973 since Arab forces were more successful in battle than they had been previously. Secondly, some Arab leaders were determined to avoid the blatant media distortions of 1967 because these had caused a loss of credibility at home and abroad. Rugh asserts in his article on the insisting of Arab media and Egyptian media in particular adherence to the credibility of its reports regarding war 1973. He finds that Egyptian editors were worried about maintaining their reputation, especially after publishing distorted military reports based on government sources during the 1967 war (Rugh,1975, p.322).

In "To an Egyptian Soldier", Aharoni continuous her attempts to establish her ideology in trying to convince the Egyptians that they also have something that they lost in the war, and they are at an equal place in the war. Once again, the Israeli poet tries to present her ideas through speaking in the tongue of an Egyptian pilot who appeared on Israeli television during the Yom Kippur War, October 1973:

I saw you on television last night bewildered in our land, your eyes were dim and you mumbled under your shield:

"I want to go back to my young wife and four-year-old son." (Aharoni,2018, p.69)

There is no clear explanation why Aharoni insists on presenting Egyptian soldiers in a maze between their love for their homeland and their families. It seems she tried to find something that she can put in comparison to Egyptian faith in their land and war and she finds nothing to use in her poems except family love to touch and affect readers' sensibility. Aharoni repeats the multilayer of voices technique in this poem, first, she makes the Egyptian pilot mumbling audible, and then she speaks to him "And I wanted to tell you / I know that this time you did not run away / because they told you ... Yet tonight, under Israeli skies / you ask yourself: / Why am I here" (p.69). These verses reflect that Aharoni knows that Egyptians regain the land, but desperately she sees that the sky still belongs to Israel. "Why am I here?", Aharoni tries to shake Egyptian faith towards the war and to establish an ideology that this war has no winner and by halting this war and signing a peace treaty both Egypt and Israel are triumphant "with the long longed-for / trophy of peace for both / Egypt and Israel" (p.69).

The publication of Aharoni's book of poetry the day after the date that the US moved its embassy from Tel Aviv to Jerusalem makes the researcher thinks of the significance of this timing. Although this book is alleged to carry a message of peace, according to the new historicist reading it represents an attempt to establish an ideology of containment that comes on multilevel. First, Aharoni tries to ease the Arab anger against the moving of the US embassy and recognition of Jerusalem, an Islamic holy city, as the capital of Israel. Second, she tries to convince Arabs that they lose something in the You Kippur War as well as Israel and there is no triumph at the end of the war. Third, she speaks to the young generation of Arabs in an unpretentious language without strong galloping rhythms and chiming rhymes. She uses open-form poems as they give room for more depth and intimacy with the readers. Because she knows how to establish an ideology for her readers and convince them to stop thinking about wars because they will not triumph simply. Finally, her ideology works to convince the Arabs that the only solution to maintain peace in the region is through accepting fait accompli.

\section{References}

[1] Abrams, M. H., \& Harpham, G. G. (2015). A glossary of literary terms. Cengage Learning.

[2] Aharoni, A. (1992). Poems from Israel and Other poems: Selected poems, 1972-1992. Berger Press.

[3] Aharoni, A. (2018). Toward a horizon of peace. Cook Communication.

[4] Althusser, L. (1971). Lenin and Philosophy and Other Essays (B. Brewster, Trans). New Left Books.

[5] BBC. (2019, April 9). Israel profile Timeline. BBC News.

[6] Beinin, J. (2005). The dispersion of Egyptian Jewry: Culture, politics, and the formation of a Modern Diaspora. American University in Cairo Press.

[7] Bennett, A., \& Royle, N. (2016). An introduction to literature, Criticism, and Theory. Routledge.

[8] Brannigan, J. (1998). New historicism and cultural materialism. Macmillan.

[9] Cortellessa, E. (2018, December 30). 2018, The year Donald Trump upended the Us-Israel relationship. The Times of Israel.

[10] Cuddon, J. A. (2014). The Penguin Dictionary of literary terms and literary theory. Penguin Books.

[11] Das, B. K. (2000). Twentieth-Century Literary Criticism. Atlantic Publishers and Distributors.

[12] Dina, E. (2018). Remembering the 1973 October War. Ahram Newapaper.

[13] Dina, E. (2021, April 25). The $6^{\text {th }}$ of October war: A Tale of Resilience and Glory. Ahram Newspaper. 
[14] Flood, C. (2002). Political myth: A theoretical introduction. Routledge.

[15] Foucault, M. (1990). The history of Sexuality: Volume 1: An introduction. Penguin.

[16] Greenblatt, S. J. (1984). Renaissance self-fashioning: From more to Shakespeare. University of Chicago Press.

[17] Jaffee, M. S. (1991). The Victim-Community in Myth and History: Holocaust Ritual, the Question of Palestine, and the Rhetoric of Christian Witness. Journal of Ecumenical Studies, 28, 236.

[18] Kaș Y. (2014). The Tombstone in Israel's military cemetery Since 1948: Israel'S transition From collectivism to individualism. Oldenbourg.

[19] McGann, J. J. (1985). Historical studies and Literary Criticism: 4th annual conference in the Humanities: Papers. University of Wisconsin Press.

[20] Mosse, O. L. (1990). Fallen soldiers: Reshaping the memory of the world wars. Oxford university press.

[21] Murray, C. (1999). Encyclopedia of literary critics and criticism. Fitzroy Dearborn.

[22] Myers, D. G. (2006). New Historicism in Literary Study. Academic Questions, 2.

[23] Nakamura, D. (2017). Trump to Recognize Jerusalem as Israel's Capital in Policy Shift That Could Spark Unrest. The Washington Post.

[24] Rabinovich, A. (2017). The Yom Kippur War: The epic encounter that transformed the Middle East. Schocken Books.

[25] Regine, B. (2011). Peace and the gathering power of women. The Huffington Post..

[26] Rugh, W. A. (1975). Arab Media and Politics during the October War. Middle East Journal, 29(3), 310-328.

[27] Ryan, M. (2017). Literary theory a practical introduction. Wiley Blackwell.

[28] Selden, R., Widdowson, P., \& Brooker, P. (2017). A reader's guide to contemporary literary theory. Routledge, Taylor et Francis Group.

[29] Tudor, H. (1972). Political myth. Macmillan.

[30] Ukkan, R. P. (2004). Approaching New Historicism. Critical Practice, 12(2), 22-36.

[31] Veeser, H. (2013). The New Historicism. Routledge.

[32] Wistrich, R. S., \& Ohana, D. (2014). The shaping of Israeli identity: Myth, memory, and trauma. F. Cass. 